Historic, archived document

Do not assume content reflects current scientific knowledge, policies, or practices. 

abundance during the summer. It grows about i 8 inches high. 'The flowers are produced in umbels of 4 or 5 , the outer segments being pale green on the outside, with white scarious margins. The insicle is brilliant scarlet-red, the inner segments also brilliant scarlet except for a purple spot just above the base, bearded with a few tufted hairs; the anthers are dark purple.' \$I 75-\$IO.

C. LONGIBARBATLS. A foot high; purple. I $50-600$

C. Nitrides. A form of C. Benthamii. I 50-6 00

C. Nunus. A low growing species; petals white. I I $2-450$

C. UNIFLoRts. Stem 3 to 6 in. high; lilac. I I $2-45^{\circ}$

Camassia Cusickir. Large bulbs, $250-\$ 10$.

ERITHRonimm montanum. A lovely sort from Oregon, 3 to 4 flowered-the largest of the genus, pure white, with an orange center. (E..grandiflorum albiflorum.)

E. HOWELIII. White, clianging to pink.

I $25-450$

E. Hendersoni. Purple; mottled foliage.

$250-900$ erin Oregon.

from Fiast-

FRITILLARIA LANCEOLATA GRACILIS. A striking variety, the flowers nearly black.

I $12-450$

$\mathrm{F}$. Coccinfid. A new species with one or two scarlet flowers on a stalk; very pretty.

F. ATROPURPLREA.

F. PARVIFLORA. An odd sort.

I $50-6$ oo

I $12-450$

HESPEROCALIS UNDLLATA. The Lily of the Desert; one of the most lovely of flowers, inhabiting the sandy wastes of the Mohave and Colorado deserts, where the large flowers of waxy whiteness, or tinged with green, 'waste their sweetness on the resert air.' \$I each; \$6 per doz.; \$20 per C; \$I60 per M.

I. ECCOCRINUM MONTANUM. A very pretty liliaceous plant, with delicate white flowers. I $50-6$ oo

LiLIUM PARRYi. Delicate lemon yellow. \$5一20

L. PARVTM. True,

$\$ 3-\$ 12 \quad 50$

L. IIARITIMUM. Blood red.

$\$ 375$-\$15

L. RUBFSCENS. A lovely lily resembling $\mathrm{I}_{1}$. Washing tonianum, but flowers turning to wine color.

MUILLA MARITIMA.

$\$ 5-\$ 20$

ZYGADENUS FREMONTI. 'This bears paniculate racemes of cream colored flowers, the stems six inches to a foot high; known by some as the 'Star of Bethlehem.'

Z. PANICULATUS. Stouter and taller.

I I $2-45^{\circ}$

I $\mathrm{I} 2-450$

I89.- CARI, PURI)Y, UkIAH, CaIIFORNIA, U.S.A. 


\section{NOVEL AND RARE BULBS AND PLANTS.}

IN THIS LIST are mentioned many species of great beauty, as yet but little known, though well worthy of extended culture. a - Of the species here offered I have either small supplies growing or must depend on collectors this season. Through a large corps of collectors I reach nearly all parts of the Pacific Coast, and expect to secure all varieties here mentioned. I can, however, give no guarantee either as to filling orders or date of shipments. Californian sorts can usually be shipped by September I; while Oregon bulbs are rarely at hand before the last of the month; Liliums still later. Quality will be medium. Terms as in regular list. Prices quoted are per dozen and per hundred.

Alimu acuminatum. This is really a pretty species, with bright rose purple flowers.

$\$ \quad 50-2 \quad 25$

A. FAl.CIFOLIUM. Grows two or three inches high, with odd rose purple flowers. $50-2 \quad 25$

A. HAMATOCHITON. This species is rare in cultivation, being considered tender in the east; the flower is white with greenish stripes and a reddish-brown center; small. $5 \mathrm{O}-2 \quad 2 \dot{5}$

A. Fimbriatum. 'The 'lavina' of the Mexicans; a plant that any one must admire for the rich, deep rose purple color of the wax-like blossoms.

A. SERRATUM. A large stock growing.

A. UNIFOI.IUM. Flowers white to rose purple.

I $\mathrm{OO}-4$ 40

BRODIÆA CAPITATA ALBA. Very pretty.

45 - 175

B. Howeliti. A fine yellow sort from Oregon.

$40-150$

B. HENDERSONII. Oregon; yellow, purple stripes.

$60-240$

B. FILIFOLIA. Beautiful lavender, quite large.

I $00-9$ OO

I $00-9$ oo habit, lavender color.

B. TERRESTRIS. Reddish purple. strong in $70-+00$ $60-2 \quad 25$

CALOCHORTUS MACROCARPUS. A very beatutiful desert species, with large purple flowers.

I $00-4 \quad 50$

C. TOI,MIEI. This rare Oregon species is tall and stout in habit, the purple tinged white flowers much like those of $\mathrm{C}$. lilacinus. The petals are fringed with hairs.

I $40-6$ oo

C. PALMERI. A rare species of great beauty; petals white, inclined to a yellowish tint.

I $\mathrm{OO}-7 \quad 5^{\circ}$

C. Howelisi. Stems two feet high; petals white, I 25-8 OO

C. Gunnisoni. This Rocky Mountain species has light lilac petals, yellowish green below the middle, banded and lined with purple. True,

I $50-6$ oo

C. KENNEDYI. 'This 'is the most brilliant and striking of all the Calochorti known to us,' say a writer in the London Garden, who adds: 'the dazzling scarlet of the flowers suggests the iodide of mercury, and as the plant proves to be what is called a good doer, it is certain to become popular. It has proved perfectly hardy in England, the bulbs having been in the open border during the last three winters, and flowers have been produced in 